\title{
Intratumoral Bleeding in a Vestibular Schwannoma
}

\section{Sangramento intratumoral de um schwannoma vestibular}

\author{
Emanuelle Rieger Braga ${ }^{1}$ Luiza Köhler ${ }^{1}$ Marcelo de Cesaro ${ }^{1}$ Tasso Barreto ${ }^{2}$ Richard Giacomelli ${ }^{2}$ \\ Nério Dutra Azambuja J ${ }^{2}$ Daniel Lima Varela ${ }^{2}$ Paulo Moacir Mesquita Filho ${ }^{2}$ \\ 1 Faculdade de Medicina, Universidade de Passo Fundo, Passo Fundo,
Rio Grande do Sul, Brazil
2 Department of Neurosurgery, Hospital da Cidade de Passo Fundo,
Passo Fundo, Rio Grande do Sul, Brazil

\begin{abstract}
Address for correspondence Emanuelle Rieger Braga, Medical Student, Universidade de Passo Fundo Faculdade de Medicina, Rua Paissandu 1011, Passo Fundo, RS, 99010-100, Brazil
\end{abstract} \\ (e-mail: manuriegerb@gmail.com).
}

Arq Bras Neurocir 2018;37:47-49.

\begin{abstract}
Keywords

- vestibular schwannoma

- vestibular neuroma

- intratumoral bleeding

- cerebellopontine angle tumors
Resumo
Palavras-chave
- schwannoma vestibular
- neuroma vestibular
- sangramento intratumoral pontocerebelar

- tumores do ângulo

Vestibular schwannomas (VSs) account for $\sim 70 \%$ of all tumors of the cerebellopontine angle (CPA). Their clinical presentation is often insidious, with progressive hearing loss and involvement of other cranial nerves. Spontaneous hemorrhage in those tumors is very unusual, and generally presents with acute clinical features such as nausea, vomiting, headache and altered consciousness, usually with marked dysfunction of the cranial nerve involved, and with new deficits of neighboring cranial nerves. Asymptomatic patients are extremely rare. We present a case report of an incidental VS with asymptomatic bleeding, which evolved to death after surgery.

Schwannomas vestibulares (SVs) são responsáveis por cerca de $70 \%$ de todos os tumores do ângulo pontocerebelar. Sua apresentação costuma ser insidiosa, com perda auditiva progressiva e envolvimento de outros nervos cranianos. Hemorragia espontânea nesses tumores é incomum, e geralmente apresenta-se agudamente, com náusea, vômitos, cefaleia e alterações de consciência, normalmente com disfunção importante dos nervos cranianos envolvidos e com novos déficits dos nervos próximos. Pacientes assintomáticos são extremamente raros. Apresentamos um relato de caso de um SV incidental com sangramento assintomático que evoluiu para o óbito após cirurgia.
\end{abstract}

\section{Introduction}

Vestibular schwannomas (VSs) account for $8 \%$ of intracranial tumors and $\sim 70 \%$ of all tumors of the cerebellopontine angle (CPA). ${ }^{1}$ The clinical presentation is often insidious, with progressive hearing loss and involvement of other cranial nerves (CNs), primarily the facial (VII) and the trigeminal (V) nerves. Spontaneous hemorrhage in those tumors is very unusual, and generally presents with acute clinical features, resulting in higher mortality. ${ }^{2}$

received

October 28, 2017

accepted

November 22, 2017

published online

December 18, 2017 10.1055/s-0037-1615287. ISSN 0103-5355.

\section{Case Report}

A 66-year-old female patient, a 30-year smoker with a history of heavy alcohol consumption, was hospitalized for gastrointestinal bleeding, and underwent a computed tomography (CT) scan for evaluation. The CT scan evidenced an expansive lesion in the cerebellopontine region. A magnetic resonance imaging (MRI) scan of the brain revealed a lesion with a $2.5-\mathrm{cm}$ diameter, with the features that characterize a VS. The patient was referred to neurosurgery for treatment

Copyright $\odot 2018$ by Thieme Revinter Publicações Ltda, Rio de Janeiro, Brazil

\section{License terms}


after 1 month, and a new MRI showed a 1-cm increase in the lesion, as well as intratumoral bleeding.

In the preoperative evaluation, the patient presented right auditory deficit, as well as facial and trigeminal nerve deficits, with no history of neurological comorbidities. Subtotal surgical resection of the tumor was performed, combined with neuromonitoring, and there were no complications during this period. In the immediate postoperative period, the patient progressed well, reaching a score of 15 on the Glasgow Coma Scale (GCS). About 12 hours after the end of the procedure, the patient presented disorientation, decreasing to GCS 12, without focal deficits. An emergency CT scan evidenced an epidural hematoma in the surgical site. The patient was then taken again to surgery, with evacuation of the hematoma, and decompressive craniectomy of the suboccipital region. The patient presented a slight improvement in the sensorium, but after 6 hours she evolved to coma. A new CT scan was performed, evidencing an important cerebellar bleeding. A new surgical procedure was performed, but no clinical improvement was achieved. The patient became irresponsive, GCS 3, with fixed and dilated pupils, and died $\sim 24$ hours later.

\section{Discussion}

Vestibular schwannomas are tumors originating from Schwann cells, which form the myelin sheath, and arise from the superior and inferior vestibular portions of the eighth $\mathrm{CN}{ }^{1}$ The incidence rate of VS is of $\sim 1.2$ per 100 thousand people per year, and this rate is expected to rise, partly due to incidental diagnoses. ${ }^{3}$ Vestibular schwannomas are rare, comprising $\sim 8-10 \%$ of primary intracranial tumors, $70-85 \%$ of CPA tumors, and $90 \%$ of intracranial schwannomas. ${ }^{1,4}$

The diagnosis is made, on average, on patients around 50 years of age; $90 \%$ of the cases are unilateral, and the involvement is equal on both sides. ${ }^{2}$ The symptoms are usually insidious, and are mainly caused by vestibular-cochlear nerve involvement. Approximately $95 \%$ of the patients have hearing loss, although only $2 / 3$ are aware of that loss, and tinnitus (60\%) is usually among the clinical features. ${ }^{3}$ Vestibular involvement occurs in $61 \%$ of the cases, and most patients acknowledge unsteadiness while walking. The trigeminal nerve can also be affected in up to $17 \%$ of the patients, as well as the facial nerve in $6 \%$ of the cases. ${ }^{5}$ Though unusual, the presentation can be of catastrophic onset, resulting from sudden, massive intratumoral hemorrhage or subarachnoid hemorrhage $(\mathrm{SAH}) .^{5}$ The management of elderly patients diagnosed with VS is generally conservative, consisting of observation and routine radiographic monitoring of tumor size progression and new symptom development. ${ }^{3}$

Vestibular schwannomas are isointense to hypointense to brain on T1-weighted images, and hyperintense on T2-weighted images and enhanced after the administration of intravenous (IV) contrast. They may be heterogeneous due to cystic degeneration, hemorrhage or vascularity. ${ }^{6}$ Vestibular schwannomas are histologically benign tumors, and a significant proportion of them are either non-growing or slow-growing; therefore, observation is a commonly accepted option in case of small oligosymptomatic tumors ( $<2.5 \mathrm{~cm}$ in size). Microsurgery is indicated mainly in the case of large tumors, the deterioration of useful hearing during observation with attempt for its preservation, and in the case of disabling symptoms. ${ }^{4}$

Hemorrhage from brain tumors accounts for $1-11 \%$ of intracranial bleeding, and 1-2\% of the hemorrhages occur beneath the arachnoid membrane including the 3 following types: $\mathrm{SAH}$, intratumoral hemorrhage (ITH) with $\mathrm{SAH}$, and intracerebral hematoma surrounding the brain tumor with $\mathrm{SAH}^{7}$ Severe bleeding causes complications in up to $10 \%$ of the cases. ${ }^{2}$ Intratumoral hemorrhage within a VS, however, is considered a rare event. ${ }^{8-10}$ It has been historically reported in less than $1 \%$ of the cases. ${ }^{9}$ Advances in imaging and larger analyses suggest that ITH is far more common than what was previously believed, and it might represent an aspect of the natural history of VS. ${ }^{9}$

Different theories have been proposed to explain the pathogenesis of the hemorrhage. An invasion of the vascular wall by tumor cells, and vascular proliferation followed by necrosis are plausible explanations. ${ }^{8}$ Hypertension, contusion of the tumor, and rapid growth are also blamed for the hemorrhage in cases of acoustic neurinoma. Marked increase in arterial and venous pressure by physical exercise and traumatic contusion of the tumor may rupture the fragile tumor vessels, resulting in massive hemorrhage in cases of acoustic neurinoma. A rapidly growing tumor disrupts the adjacent thin-walled and dilated vessels, leading to massive hemorrhage into the surrounding tissue, where stromal support is weak. ${ }^{5}$ Different risk factors have been suggested for ITH in cases of VS, which include tumor size ( $>2 \mathrm{~cm}$ ), abnormal vasculature, radiosurgery, and rapid growth of the tumor. The use of anticoagulants, methotrexate, cocaine, and trauma may result in ITH, even though only a few cases have been reported. $^{7-9}$

Most patients with neuroma-related hemorrhage presented with nausea, vomiting, headache and altered consciousness, usually with marked dysfunction of the $\mathrm{CN}$ involved, and commonly with new deficits of the neighboring CNs. Asymptomatic patients, as in our case, were described in very few reports. ${ }^{2,10}$ The clinical impact of ITH in cases of VS is likely substantial, as the existing literature records an increased prevalence of CN-VII palsy at presentation and an increased rate of death when compared with non-hemorrhagic cases. For example, the reported incidence of $\mathrm{CN}-\mathrm{VII}$ palsy in large series of cases of VS is of $\sim 6 \%$, but a review by Niknafs et al of hemorrhagic VSs revealed CN-VII palsy in $31.3 \%$ of the cases. ${ }^{9}$

The prognosis of the patients with ITH secondary to a neoplasm is usually poor. ${ }^{5}$ However, a variable prognosis is described in cases of hemorrhagic VS. ${ }^{2}$ Surgical evacuation of the hematoma and tumor excision comprise the preferred method of treatment for hemorrhage in cases of acoustic neurinoma. Batuk et al mention 1 series in which, out of 36 patients who underwent surgery, only 2 died, and all the rest had uneventful postoperative courses and good outcomes. ${ }^{5}$

\section{Conclusion}

Intratumoral bleeding in cases of VS is rare, and usually presents with acute symptoms, such as neurological deterioration or SAH. ${ }^{11}$ In the present case, we report a patient with an accidental discovery of the tumor, which evolved with rapid 
growth and bleeding, but without clinical changes. Even after surgical resection, the prognosis varies greatly, from total recovery and return to daily activities to death, ${ }^{2}$ which was the progression of our patient's condition.

\section{Conflicts of Interest}

The authors have no conflicts of interest to disclose.

\section{References}

1 Castillo R, Watts C, Pulliam M. Sudden hemorrhage in an acoustic neuroma. Case report. J Neurosurg 1982;56(03):417-419. Doi: $10.3171 /$ jns.1982.56.3.0417

2 Goetting MG, Swanson SE. Massive hemorrhage into intracranial neurinomas. Surg Neurol 1987;27(02):168-172. Doi: 10.1016/ 0090-3019(87)90290-4

3 Sylvester MJ, Shastri DN, Patel VM, et al. Outcomes of Vestibular Schwannoma Surgery among the Elderly: Analysis of the National Inpatient Sample. Otolaryngol Neck Surg 2017;156(01):166-172. Doi: $10.1177 / 0194599816677522$

4 Betka J, Zvěřina E, Balogová Z, et al. Complications of microsurgery of vestibular schwannoma. BioMed Res Int 2014;2014:315952
5 Diyora B, Sharma A, Badhe P, Nayak N. Hemorrhage in acoustic neurinoma. Neurol India 2010;58(02):329-330. Doi: 10.4103/00283886.63775

6 Yilmaz C, Altinors N, Sonmez E, Gulsen S, Caner H. Rare lesions of the cerebellopontine angle. Turk Neurosurg 2010;20(03): 390-397. Doi: 10.5137/1019-5149.JTN.2961-10.0

7 Gavra M, Thanos L, Pomoni M, Batakis N. Spontaneous subarachnoid haemorrhage due to acoustic neurinoma. Case report and review of the literature. Br J Neurosurg 2010;24(01):82-83. Doi: $10.3109 / 02688690903506085$

8 Banaama S, van Overbeeke J, Temel Y. An unusual case of repeated intracranial hemorrhage in vestibular schwannoma. Surg Neurol Int 2016;7(38, Suppl 37):S869-S871. Doi: 10.4103/2152-7806.194494

9 Niknafs YS, Wang AC, Than KD, Etame AB, Thompson BG, Sullivan SE. Hemorrhagic vestibular schwannoma: review of the literature. World Neurosurg 2014;82(05):751-756. Doi: 10.1016/j. wneu.2013.02.069

10 Brady AP, Stack JP. Case report: magnetic resonance demonstration of haemorrhagic acoustic neuroma. Clin Radiol 1994;49(01): 61-63. Doi: 10.1016/S0009-9260(05)82918-6

11 Lee J-P, Wang AD-J. Acoustic neurinoma presenting as intratumoral bleeding. Neurosurgery 1989;24(05):764-768. Doi: 10.1227/00006 123-198905000-00020 